\title{
Selection of Landfill Sites for Solid Waste Treatment in Damaturu Town-Using GIS Techniques
}

\author{
Ayo Babalola, Ibrahim Busu \\ Department of Remote Sensing Faculty of Geo-information Science and Engineering, Universiti Teknologi Malaysia, Johor state, Malaysia. \\ Email: babaayo547@gmail.com, ibusu@utm.my
}

Received September $29^{\text {th }}$, 2010; revised November $10^{\text {th }}$, 2010; accepted December $24^{\text {th }}, 2010$.

\begin{abstract}
Landfill has been recognized as the cheapest form for the final disposal of municipal solid waste and as such has been the most used method in the world. However, siting landfill is an extremely complex task mainly due to the fact that the identification and selection process involves many factors and strict regulations. For proper identification and selection of appropriate sites for landfills careful and systematic procedures need to be adopted and followed. Wrong siting of landfill many result in environmental degradation and often time public opposition. In this study, attempts have been made to determine sites that are appropriate for landfill siting in Damaturu town Nigeria, by combining geographic information system (GIS) and a multi-criteria decision making method (MCDM) known as the analytic network process (ANP) for the determination of the relative importance weights of factors (criteria). The land suitability output is presented from less suitable to the most suitable areas. The final map produced show areas that are suitable for landfill siting. Based on the analysis fourteen sites were identified to fulfill the required criteria, however, only seven met the land availability criteria of twenty hectares and above. The results showed the efficacy of GIS and multi-criteria decision making method in decision making.
\end{abstract}

Keywords: Municipal Solid Waste Management, Damaturu, Nigeria, Geographic Information System (GIS), Landfill Siting, Ikonos

\section{Introduction}

The growth in municipal solid waste generation the world over as a consequence of urbanization, industrialization, and population growth, together with improved living standards has been widely reported [1]. Municipal solid waste has also been recognized as one of the major problems confronting governments and city planners the world over [2]. It is estimated that the United kingdom produces 35 million tones of municipal solid waste annually [3], and in the United states of America, more than 140 million tones of municipal waste is generated annually, while Japan and Germany generates 50.2 million and 43.5 million tones of municipal wastes in 1993 respectively [4]. India, one of the most populous countries in the world generates between 500-700 gm per head per day [1]. In Africa, the situation appears to be the same as other parts of the world. Nigeria with a population growth rate of about $2.8 \%$ per annum and an urban growth rate of about 5.5\% per annum [5] generate about
$20 \mathrm{~kg}$ of Solid waste per capita every year [6]. Thus, a proper waste management practices is very much in need to handle the situation in Nigeria .In the developed countries, the issue of solid waste is properly handled through the effective management process of waste reduction, reuse recycle and proper disposal. In the developing countries, municipal solid waste management system is either not efficient or still at the rudimentary stage and as such solid waste generated has become a threat to the environment. The growth in population, urbanization, industrialization, and waste generation in the developing countries calls for proper solid waste management as it has become a necessity for environmental conservation [1] and Sustainability. For a sustainable solid waste management system policies and techniques such as waste recycling, reuse, waste reduction, thermal treatment, landfilling etc, must be in place. The landfill method has been widely recognized as the most used of all the waste management techniques. This paper presents a study that 
utilizes a geographic information system and multi-criteria decision method techniques for the selection of landfill sites in Damaturu town.

\section{Materials and Methodology}

Damaturu the study area is located in the north eastern part of Nigeria and lies between longitudes $11^{\circ} 42^{\prime}$ and $11^{\circ} 57^{\prime}$ and between latitudes $11^{\circ} 54^{\prime}$ and $12^{\circ} 01^{\prime}$ and area coverage of about $48.10 \mathrm{sq}$ km (Figure 1) The Temperature of Damaturu ranges between $30^{\circ} \mathrm{C}$ and $42^{\circ} \mathrm{C}$, and the rainfall ranges between $400 \mathrm{~mm}$ and $800 \mathrm{~mm}$ and annual mean of $750 \mathrm{~mm}$. Aside from the northeast trade wind that is associated with dry season, there is the southwest maritime air masses that is associated with the wet season.

The population of the town has been estimated to be about 255,895 [7]. Most recently the increase in population as well as the economic growth in the study area has transformed and urbanized the area and led to the change in landuse and a substantial increase in municipal solid waste generated.

Solid waste management system in the town is not effective as wastes are seen dumped on all manner of places including roads, near sensitive areas, and on private properties. It is therefore of importance that solid waste collected are properly disposed at designated sites in the city in order to avoid environmental degradation.

In locating proper sites (Landfills), consideration is giving to environmental factors mainly to avoid environmental risk. Again landfill site should be located far from residential areas and settlement. The site should be away from areas that are susceptible to flooding, as this could result in washout of disposal waste into groundwater or stream and would pose risk to human health, the local aquifer [8] and the environment. Other factors relating to land use, roads, slope, wind direction etc are considered in locating a risk free and environmentally friendly waste disposal site. These spatial information and other related factors have been used in identifying

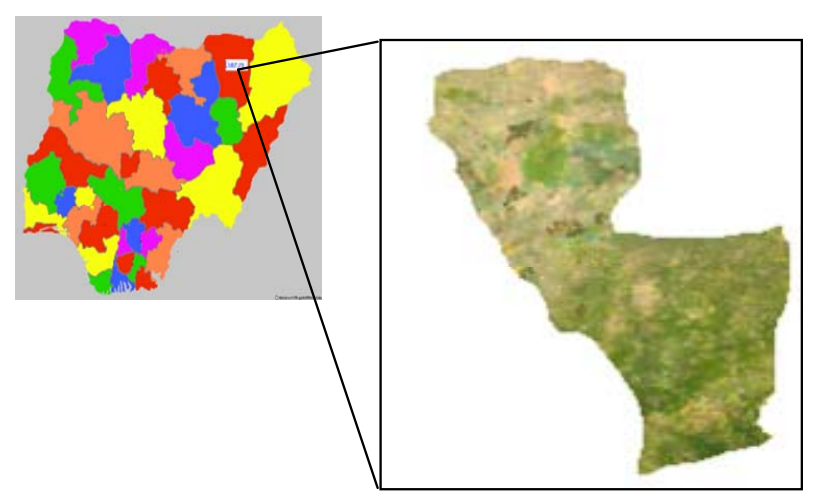

Figure 1. Map of Nigeria showing Damaturu the study area. and selecting landfill site in Damaturu town of Nigeria. Recent improvement in computer processing and the introduction of Geographic information system (GIS) as a tool for siting of waste disposal site (landfill) has further exposed the importance and the complexities involved in landfill siting process.

Recent research work on the application of GIS for the siting of waste disposal sites include [9,11,12] and [13]. Landfill siting basically considers multiple data and from different sources as may be observed in the next segment of data collection and processing.

\subsection{Data Collection}

Subsets of IKONOS satellite imageries covering the study area on Scale 1:3000 as well as 1:2000 topographic maps were used to extract the following information layers of the town: the Land use which comprise of residential areas, settlement, roads, water bodies, groundwater, commercial areas, sensitive areas, recreation, educational institution, agricultural, etc. Others are slope from the contour intervals as extracted from the topographic maps, rainfall data, wind direction and speed, and soil. The geographic data and features required for the preliminary stage of the screening of the sites are extracted using ArcGIS processing software, the primary processing steps are describe below.

The following procedures were used to ascertain needed digital thematic maps:

- Scanning of the primary maps available

- Georeferencing the scanned maps based on the ground coordinates collected through ground truth.

- On screen digitizing of the primary maps, were done in order to generate the digital thematic maps, each representing the influencing factor for landfill site selection.

- Locating the global positioning system (GPS) coordinates and entering in the database as latitude and longitude.

- Conversion of the coordinates into point data and the addition of the attribute data into the desired locations.

\subsubsection{Siting Criteria}

Selection of site is a very important process for a successful operation of a waste disposal using landfill method. Landfill involves an extensive evaluation process in order to identify the optimal available disposal location. This location must satisfy basic government regulations, and also take into cognizance how to minimize important factors like health, economic, environmental and social cost [13]. In fact, different researchers have used varying criteria for site selection purposes due mainly to the fact that different criteria applies to different region and all 
facilities [14,15].

Evaluation criteria such as water permeability, depth of the underground water table, and distance from rivers, distance from residential areas, and distance from roads, slope, and wind orientation were considered in [11]. In another study, the land slope, soil characteristics, depth to groundwater, surface water, environmentally rare or endangered species breeding areas, distance to residential, religious and archaeological sites, land use, major infrastructure systems (e.g. electric transmission lines, water or sewer pipelines), seismic activity, land cost, distance from high way, distance from waste generation source, site capacity, distance from air port run way [9] were used. However, addition factors to the aforementioned may be considered based on the local conditions and circumstances [9] or may be modified based on the geographic and demographic constraints of the research area [16].

In this study, criteria considered were based on established guidelines, and that of Yobe state environmental protection agency (YOSEPA), and modified according to available datasets for landfill siting. The selection of waste disposal site was carried out through some screening process. A GIS-based constraint mapping was employed to eliminate the environmentally unsuitable site and to narrow down the number of sites for further considerations. However most of the data and spatial information are in the analogue or hardcopy format, thus requiring scanning and digitizing in order to convert them into GIS format. In order to determine landfill suitability analysis data layers were converted from one form to the other, e.g. vector to raster. Reclassification of layer's value were done into the 1's and 0's scoring system, where 0 represented unsuitable and 1 signified suitable. Buffering was done on various layers to determine values to assign suitable or unsuitable, for instance, pond was buffered by $100 \mathrm{~m}$ and areas within the buffer were assigned a value of 0 , while areas outside were assigned the value of 1 . Overlay of generated buffer maps were done in order to identify sites where the constraints parameter will be employed (sites not permissible for landfill).

Analyses through overlaying of various thematic layers which form the set of identified criteria were then performed. Followed by, the evaluation of the composite suitability index scores in the base map. GIS-based constraint mapping approach was done to eliminate areas that are not suitable. Finally, identification of optimized site for landfill using the model was performed.

The major data used are satellite data, topographic maps, rainfall, and soil depth, geo-spatial data (latitude and longitude), wind speed and direction. The acquired data are entered into the GIS and then processed which then paved way for the actual processing segment. The data were processed using the Arc GIS software.The initial part bears vector maps, which form the layers of land use, rainfall, soil, slope, aspect, etc. All these layers were then entered into the model builder and thereafter converted to raster (grid) format from where buffering of all the constraint mapping were carried out. After this, classification was done and union of all the buffered layers. The model builder utilizes the weighted overlay procedure. In this process output map is produced from the combination of values arising from multiple input layers. The layers bear cells and these cells are weighted, all the layers are then overlaid to produce the overall output map. In this study the relative importance weight for each factor was obtained from the use of pair-wise comparison matrix method from a decision making process called the Analytical Network Process (ANP) [17-19] and carried out using the Super decisions software. The ANP has been found to be able to deal with interdependency among different layers of criteria that results in composite weights that are used to create a 'super matrix' [18].

The Analytic Network Process (ANP) was used for the determination of the weight of factors which were; landuse (0.168772), groundwater $(0.167428)$, rainfall $(0.162763)$, aspect $(0.069989)$, slope $(0.100784)$, roads $(0.060059)$, soil (0.169422) and waterbody (0.100784), after assigning weights and rating score based on the significance of the criteria and the range of magnitude of the parameter value respectively. The pairwise comparisons used in this work appear to be reasonable as generated from the use of the ANP.

To derive the elevation and the slope maps, point data of longitude, latitude and their elevations were processed in GIS environment to produce the contour maps using the surface analysis module of the Arc GIS software. From the contour maps the digital elevation model (DEM) was created from which the slope layers were derived. The land use was obtained through interpretation of Ikonos satellite image from 2005 together with a development plan of the study area. Twelve different land use types (Figure 2) were identified and categorized using visual interpretation and then digitized to create land use layers. These were sensitive areas, water body, settlement, recreation, public amenity, commercial areas, agriculture, administrative areas, low dense areas, educational areas, high dense areas and medium dense areas.

The road layer was also digitized from the satellite image and categorized into major, minor and other roads. Soil layers were derived from soil map and thereafter overlaid to produce the desired composite map. The rainfall layer and the groundwater layer were prepared. The groundwater layer was prepared from the well depth data collected from the ministry of water resources of the 


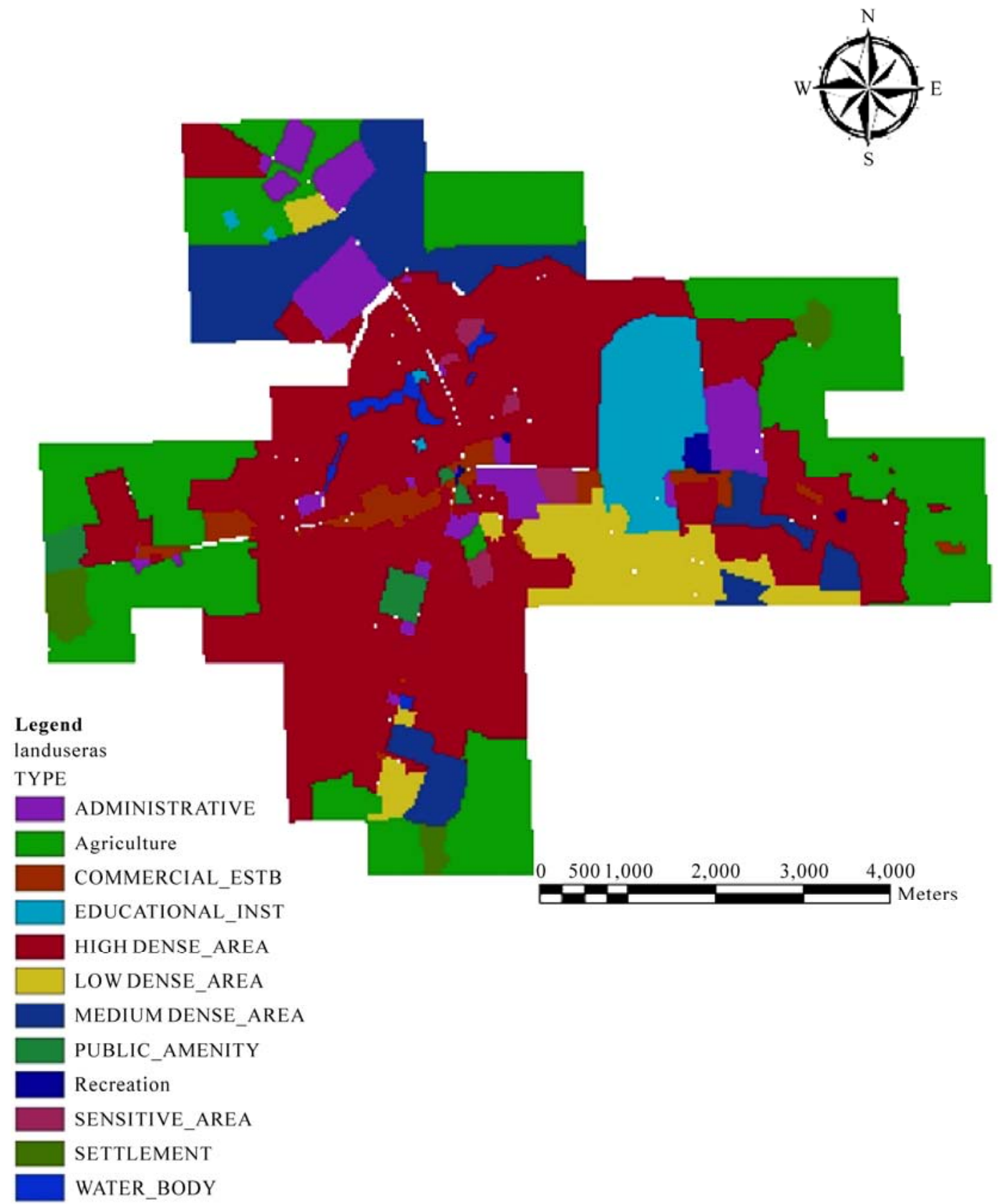

Figure 2. Land use classification.

state. The processed layers were either in raster or vector format was combined in the decision support system.

The land use pattern of the study area comprise of high dense area with 1978.83 hectares representing 41.14\%, agricultural land occupying 1289.455 hectares representing $26.8 \%$, while the medium dense area, low dense area, administrative area, educational institution, commercial area, settlement, public amenity, sensitive area, water body, and recreation, occupies 4.59, 2.9, 2.53, 2.37, 1.02, 0.66, $0.55,0.37,0.27$ and $0.15 \mathrm{~km}^{2}$ respectively or $9.53 \%$,
6.04\%, 5.27\%, 4.92\%, 2.13\%, 1.38\%, 1.14\%, 0.77\%, $0.56 \%$ and $0.32 \%$ respectively are the other land use categories and the respective area coverage.

\subsubsection{Road Network Map}

The road network map delineating the national highways and other major roads criss-crossing the town of Damaturu was prepared. There are four national roads highways passing through the town. The Damaturu-Maiduguri road moving along the eastern part of the town, the 
Damaturu-Jos along the western part of the town, the Damaturu-Gashua road along the northern part and the Damaturu-Biu road along the southern part of the town. Others are minor roads within the town

\subsubsection{Infiltration Map}

An infiltration map was produced taking into cognizance the various soil types existing in the town. The infiltration rate is an important determinant in assessing the potential risk of contamination of groundwater and thus is a major criterion for the development of landfill in the study area. Damaturu town fall within the Chad basin aquifers which remain exposed to continuous loss of rain, high evapotranspiration and less infiltration rate [20].

\subsubsection{Elevation Map}

The elevation of the study area generally ranges between 0 and 30 meters. Elevation is an important parameter in the identification of landfill site. In the method used here, the land morphology was evaluated using the grading of the slope and specified in degrees format. The sites identified to be steep are not considered as they are not suitable for landfill siting. The grading was based on the assumption that flat areas are better and more suitable for landfill siting than areas that are on a steep.

\subsubsection{Groundwater Table Map}

The groundwater table is said to be the distance between the ground surface and the water table. The depth of groundwater table is a significant parameter in determining the contamination risk of groundwater in order to limit potential contamination. Research has shown that precipitation, site topography and soil type affects the rate of infiltration into the water table [21]. From available data, it shows that the groundwater table is shallow as the depth ranges between $1.7 \mathrm{~m}$ and $6.5 \mathrm{~m}$, with the exception of few areas where the water table is between $33 \mathrm{~m}$ and $125 \mathrm{~m}$. Areas within $5 \mathrm{~m}$ distance from water table are considered to be unsuitable for siting landfills. Based on the analysis, suitability is found in areas greater than $5 \mathrm{~m}$, that is, $5-15 \mathrm{~m}$ and $15-20 \mathrm{~m}$ as less and more suitable respectively.

\subsubsection{Wind Orientation and Pattern}

The wind orientation and pattern is not known to be subject to any legal restrictions but based on the premise that landfill site should not be in the direction of the wind [22]. It is also an established fact that the direction and velocity of winds vary with altitude, slope, aspect, and terrain roughness [23]. The site morphology, wind orientation frequency and pattern of the study area were taking into consideration when developing the site selection criteria. The morphological aspect was determined in degrees, and the wind frequency is in meters/seconds. The southeast and west records the least frequent winds in Damaturu town with about 3.81 and $4.06 \mathrm{~m} / \mathrm{s}$ respectively and were therefore, assigned the highest values of suitability. But from the records the northeast winds $(5.63 \mathrm{~m} / \mathrm{s})$ is the most frequent in the study area, and as a result sites that are within such orientation are giving low values or grades. In view of this fact, areas that are on flat terrain are given the least grades, because these areas are susceptible to wind from all directions.

\subsubsection{Distance from Residential Areas}

Research has shown that as the distance from residential areas increases, the issues of public opposition to siting of waste disposal facility diminishes [11,24]. It is as a result of this fact that the suitability of site increases as public opposition diminishes. The waste disposal sites should not be sited or located in populated urban or rural areas. It is for this reason that the residential areas were categorized into high dense, medium dense and low dense areas and digitized accordingly based on the development plan available of the study area. The extent of the residential areas were derived from reclassification, and distance of $500 \mathrm{~m}$ and above are considered as suitable while $200 \mathrm{~m}$ and below were considered unsuitable. Hence the land suitability for landfill increases with the increase in distance from the residential areas.

\subsubsection{Distance from Road Network}

This criterion is concerned with the distance from the road network. The road network in the city consists of major roads, minor roads and others. The waste disposal sites should not be too close to the road networks [10, 25]. In deriving the roads layers, on-screen digitizing was performed in order to generate the vector layers and buffer of $600 \mathrm{~m}, 450 \mathrm{~m}$, and $300 \mathrm{~m}$ is applied to the different road networks, and thereafter converted into raster format. After which roads within $450 \mathrm{~m}$ were considered unsuitable for the siting of landfills. In this situation the suitability decreases as the distance from road network increases. Areas located further than $2000 \mathrm{~m}$ from the roads were considered to be unsuitable (Figure 3 ).

\subsubsection{Surface Waterbody}

Generally, waste disposal areas must not be sited near rivers, lakes, ponds or swamps. Under the Nigerian legislation it is clearly stated that dumping of solid waste on any water surface be it river, or lake is prohibited. However, a lake do not exist in the study area, hence this criterion was extended to take into cognizance other type of surface water like pond. Hence water body layer bearing the available pond is digitized and converted into raster format where distance of within $100 \mathrm{~m}$ from the pond was considered unsuitable, and further away as suitable.

\subsubsection{Sensitive Areas}

The sensitive sites layer was produced from on-screen 


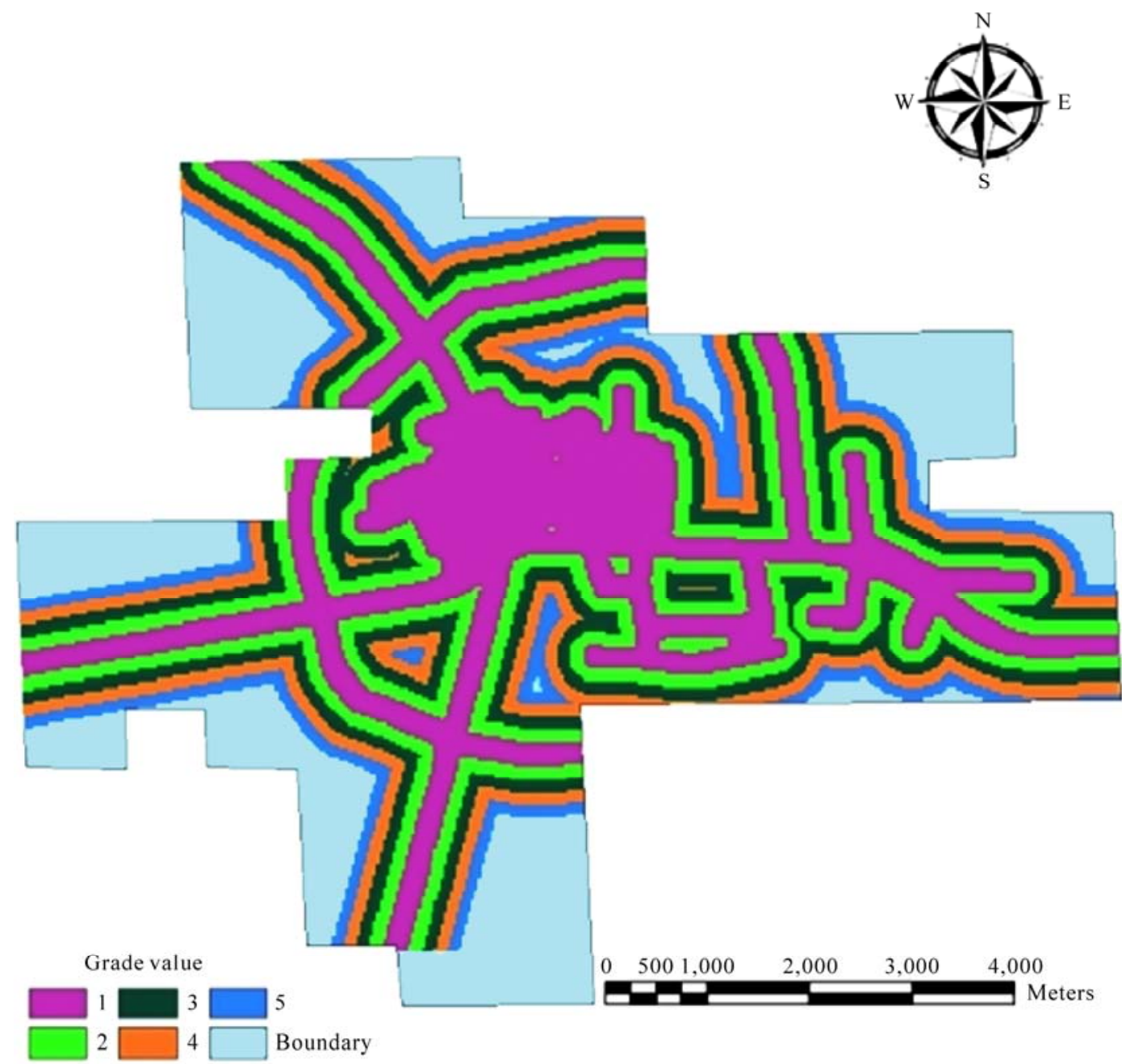

Figure 3. Accessibility (Road) classification.

digitization of areas of cultural and historical importance, these sites are exempted from landfill siting. This research considered as sensitive areas; churches, the Yobe islamic centre and graveyards and are therefore, restricted from siting landfill. These areas were digitized on a separate layer and distances within $100 \mathrm{~m}$ from these sites were considered unsuitable and distance further is considered suitable.

\subsubsection{Precipitation (Rainfall)}

The annual average rainfall data of the study area was collected and used in this study. This data was converted into Dbase format and then imported into ArcGIS as point data. In the ArcGIS environment, the data was interpolated using a widely used technique called the Inverse Distance weighted (IDW) [26]. This technique involves the interpolation of ground based point data. The process was carried out in the ArcGIS software, after which a Triangulation Irregular network (TIN) was pro- duced from it which depicted the precipitation pattern of the study area which ranges between $600 \mathrm{~mm}$ and 800 $\mathrm{mm}$. Areas within $650 \mathrm{~mm}$ were adjudged to be suitable while areas above are not suitable for landfill siting.

\subsubsection{Slope}

Slope refers to the measures of the rate of change of elevation at a surface location [27] and normally expressed in percent or degree slope. The slope map was generated from the triangulated irregular network (TIN) that was obtained from the elevation surface values through interpolation using the topographic maps on a scale of 1:2000. The areas with high slopes are not ideal for waste disposal, and flat areas are not ideal either. The preferred areas for waste disposal are those with medium slope of not more than $20^{\circ}$. Slope attribute of the area has been divided into three categories. The first category of $0-10^{\circ}$ represents suitable areas. Second category of $10-20^{\circ}$ represents areas that is less suitable. While the last cate- 
gory represents areas that are above $20^{\circ}$ and are therefore high and unsuitable for landfill.

\subsubsection{Aspect}

Aspect is simply the measure of the direction of slope. It begins with $0^{\circ}$ at the north, and then in a clockwise direction ends at $360^{\circ}$ again at the north. Aspect is often classified into four major directions namely; north, east, south, and west or into eight major directions; north, northeast, east, southeast, south, southwest, west, and northwest. The directional values are: Southeast (112157.5) ${ }^{\circ}$, West (247.5-292.5) ${ }^{\circ}$, Southwest (202.5-247.5) ${ }^{\circ}$, North (0-22.5 and 337.5-360) ${ }^{\circ}$, South (157.5-202.5) ${ }^{\circ}$, Northwest $(292.5-337.5)^{\circ}$, East (67.5-112.5) ${ }^{\circ}$ Northeast $(22.5-67.5)^{\circ}$.
The evaluation criteria discussed earlier were all considered in the raster format and were combined in a grid that bears all the grade values obtained from individual grids. Figures $\mathbf{4}$ and $\mathbf{5}$ show the suitability index and suitability classification map respectively.

\section{Results and Discussion}

The study considered the use of decision rules for the location of suitable sites for solid waste disposal, and this has been with reference to research literature, study area criteria as well as multi-criteria evaluation procedure. To arrive at the major objective of this study the suitability of the sites were classified on the basis of criteria and sub-criteria. A site is considered suitable for the location

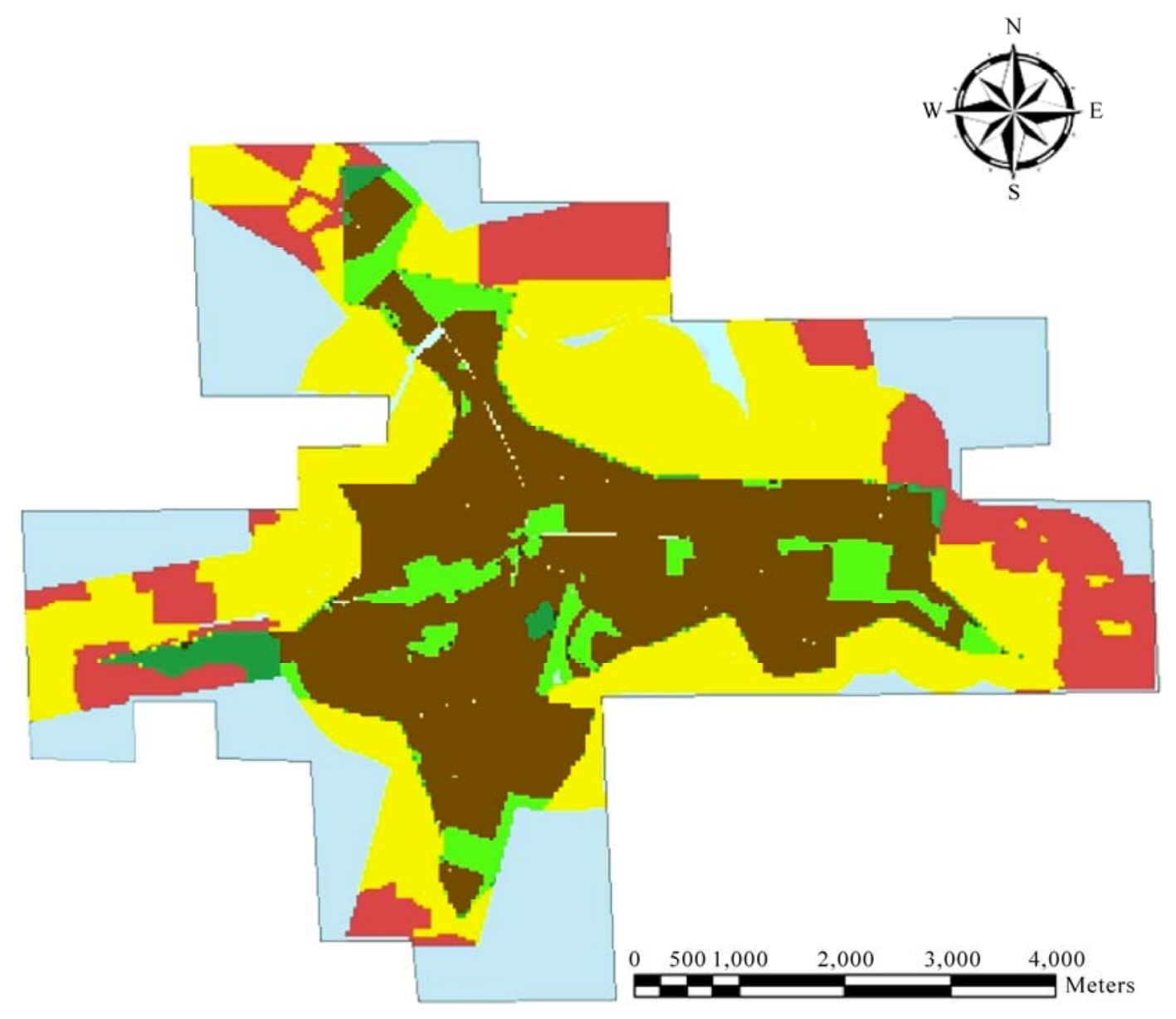

Legend

SUITABILTY < VALUE $>$

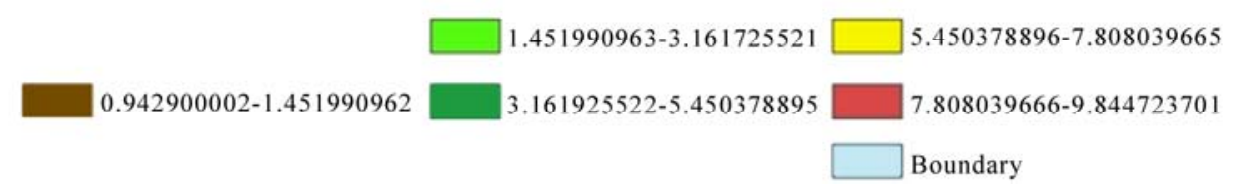

Figure 4. Land suitability index. 


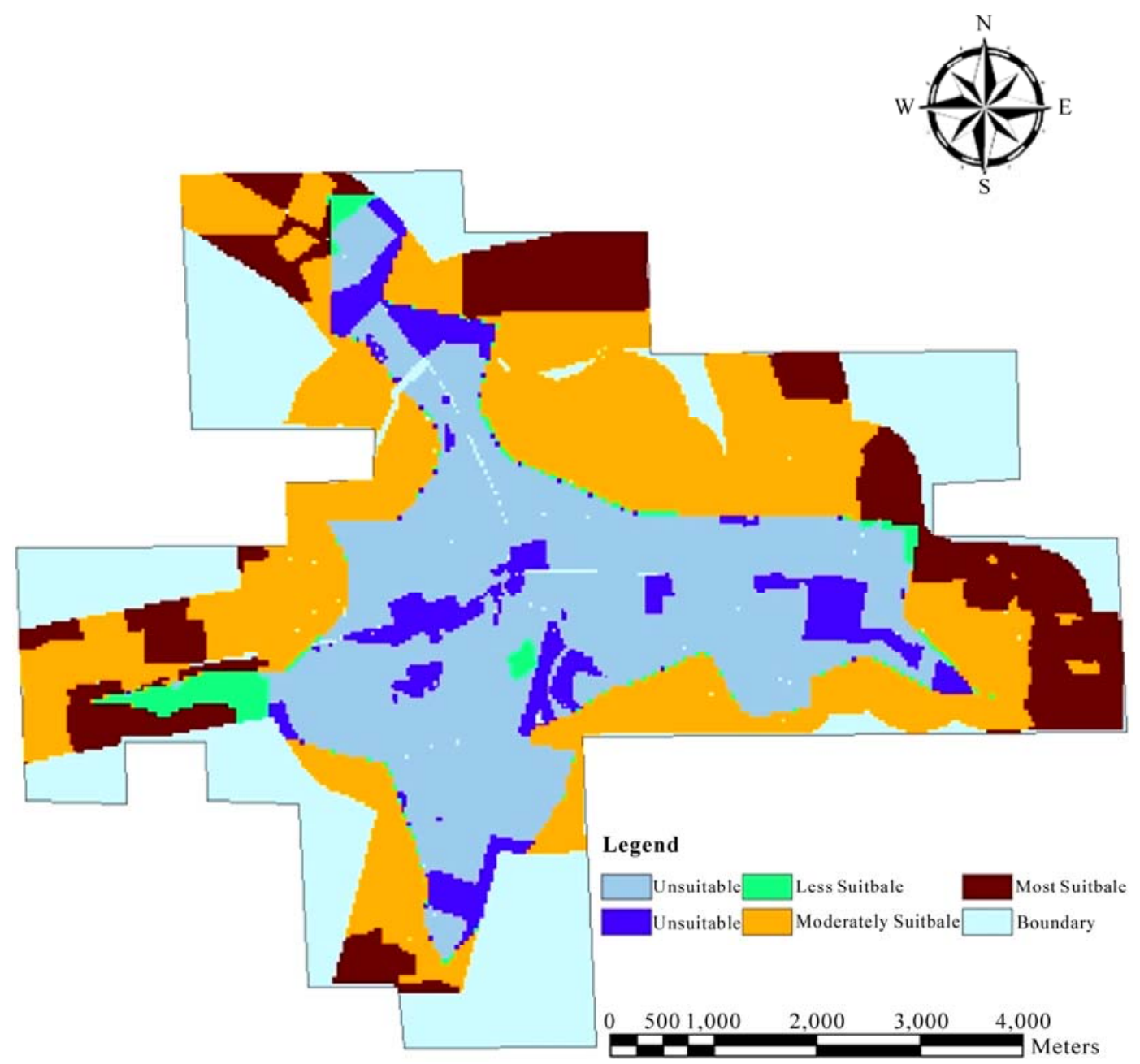

Figure 5. Land suitability classification.

of solid waste disposal if it fulfill all the requirements or criteria such as; $450 \mathrm{~m}$ from roads, $500 \mathrm{~m}$ from residential, public amenity, agricultural land, administrative offices, and educational institutions. Others are $200 \mathrm{~m}$ away from recreational and commercial area, $500 \mathrm{~m}$ from sensitive sites. The suitability of sites must also satisfy the soil type land elevation or topography, wind direction, groundwater level, and rainfall criteria. A site is considered less suitable for solid waste disposal if it fulfill all the criteria of less suitable such as; as $1500 \mathrm{~m}$ from roads, $200 \mathrm{~m}$ from residential area, $300 \mathrm{~m}$ from commercial, administrative, educational, and sensitive sites. Other considerations are the soil type, land elevation or contour, topography, wind direction, groundwater level, and rainfall. From the GIS and Multi-criteria analysis performed fourteen sites were identified as those that fulfilled the required criteria but only seven of these sites met the land availability criteria of 20 hectares and above as shown in Figure 6.

\section{Conclusions}

The methodology employed in this study described the GIS and Multi-criteria techniques for the selection of suitable sites for the disposal of municipal solid wastes in Damaturu town. The study shows the ability of GIS as a veritable tool for decision support. The techniques considered a number of siting criteria ranging from accessibility, land use, to natural factors which are very important in identifying as well as in locating sites which poses minimum or no risk to the environment. In the initial analysis which comprise of the use of Analytic Network Process (ANP) to determine the relative weights of factors and multiple criteria suitability in raster GIS, fourteen sites were selected as a result of the query for suitability. Finally, seven sites were selected for the management of solid waste in the study area. Research has shown that siting criteria can be modified based on local constraints, as such this study considered the available and important criteria. Most of the data available and 


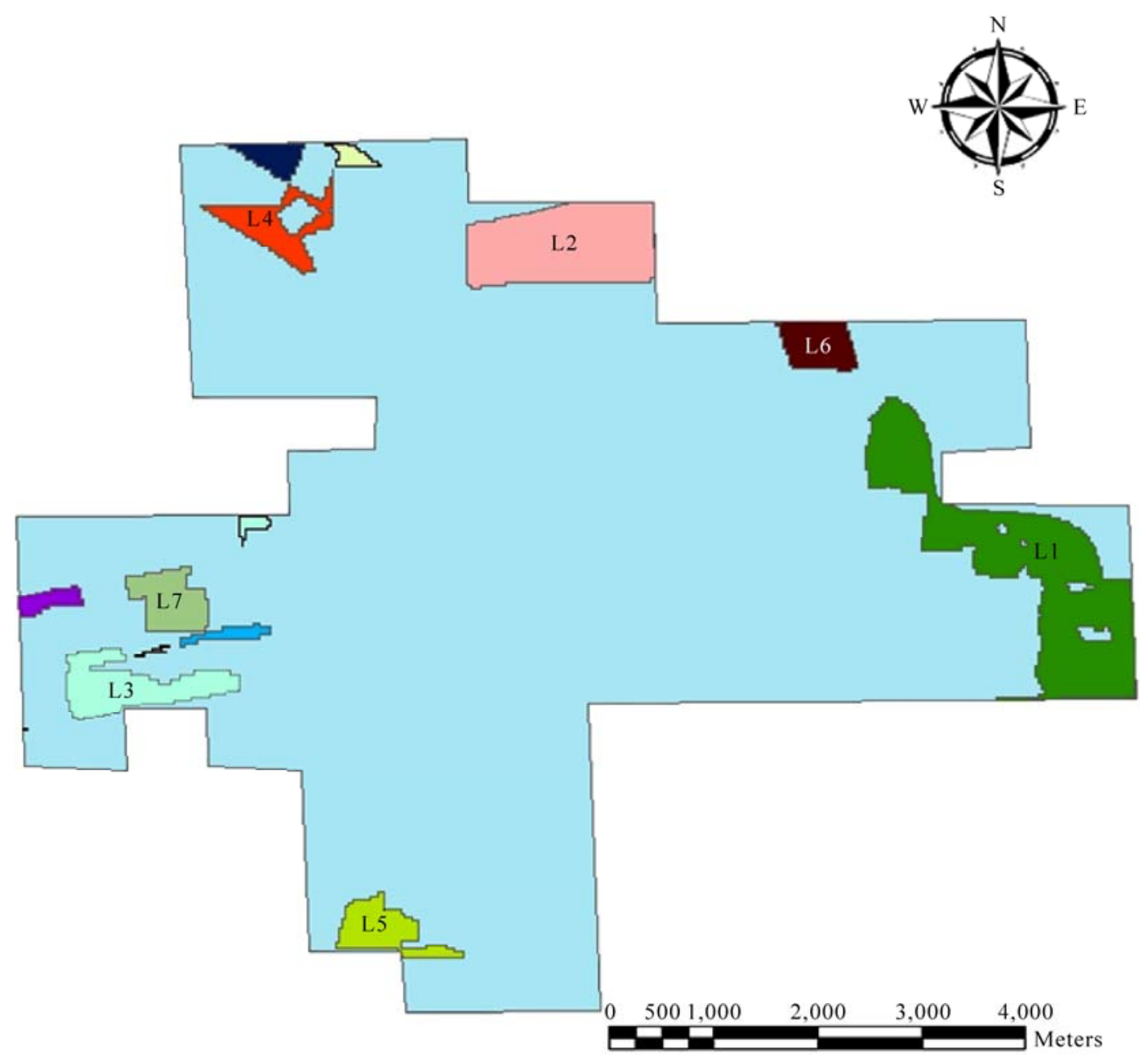

Figure 6. Selected suitable sites (Area $>20$ hectares).

collected were in the analogue format hence most of the information was derived using the GIS techniques. The study also demonstrated the efficacy of GIS in the site identification and selection process and can therefore be applied elsewhere for siting purposes.

\section{REFERENCES}

[1] P. J. Rao, V. Brinda, B. S. Rao and P. Harikrihna, "Selection of Landfill Sites for Solid Waste Management in and around Visakhapatnam City-A GIS Approach,” Asian Journal of Geoinformatics, Vol. 7, No. 3, 2007, pp.35-41.

[2] M. Rahman and A. Hoque, "Site Suitability Analysis for Solid Waste Disposal Using GIS: A Case Study on KCC Area,” The Journal of Geo-Environment, Vol. 6, 2006, pp. 72- 86.

[3] L. Koshy, P. Emma, L. Sarah, J. Tim and B. Kelly, "Bioreactive of Leachate from Municipal Solid Waste Assessment of Toxicity," Science of the total Environment, Vol. 384, No. 1-3, 2007, pp. 177-181. doi:10.1016/j.scitotenv.2007.06.017
[4] S. Sakai, S. E. Sawell, A. J. Chandler, T. T. Eighmy, D. S. Kosson, J. Vehlow, H. A. Van der Sloot, J. Hartlen and O. Hjelmar, "World Trends in Municipal Solid Waste Management,” Waste Management, Vol. 16, No. 5-6, 1996, pp. 341-350. doi:10.1016/S0956-053X(96)00106-7

[5] A. Imam, B. Mohammed, D. C. Wilson and C. R. Cheeseman, "Solid Waste Management in Abuja, Nigeria," Journal of Waste Management, Vol. 28, No. 2, 2008, pp. 468-472.

[6] J. B. Olaleye and J. O. Sangodina, "Environmental Protection and Management," Paper Presented at the $32^{\text {nd }}$ Surveyors’ Annual General Conference, Nigeria, 2000.

[7] GeoNames. "Geographical Database”, 2010. Internet Available: http://www.geonames.org/search.html

[8] S. Mohan and R. Gandhimathi, "Solid Waste Characterization and Assessment of the Effect of Dumping Site Leachate on Groundwater Quality: A Case Study,” International Journal of Environment and Waste Management, Vol. 3, No. 1-2, 2009, pp. 65-77. doi:10.1504/IJEWM.2009.024700

[9] O. Al-jarrah and H. Abu-Qdais, "Municipal Solid Waste 
Landfill Siting Using Intelligent System,” Waste Management,Vol. 26, No. 3, 2006, pp. 229-306.

[10] V. Akbari, M. A. Rajabi, S. H. Chavoshi and R. Shams, "Landfill Site Selection by Combining GIS and Fuzzy Multi-Criteria Decision Analysis, Case Study: Bandar Abbas, Iran,” World Applied Sciences, Vol. 3, No. 1, 2008, pp. 39-47.

[11] S. A. Mahini and M. Gholamafard, "Siting MSW Landfills with a Weighted Linear Combination Methodology in a GIS Environment," International Journal of Environmental Science Technology, Vol. 3, No. 4, 2006, pp. 435-445.

[12] T. Hatzichristos and M. Giaoutzi, "Landfill Siting Using GIS, Fuzzy Logic and Delphi Method,” International Journal of Environmental Technology and Management, Vol. 6, No. 1-2, 2006, pp. 218-231. doi:10.1504/IJETM.2006.008263

[13] M. Z. Siddiqui, J. W. Everett and B. E. Vieux, "Landfill Siting Using Geographic Information Systems: A Demonstration,” Environmental Engineering, Vol. 122, No. 6, 1996, $\quad$ pp. 515-523. doi:10.1061/(ASCE)0733-9372(1996)122:6(515)

[14] D. S. Stinnette, "10 Steps to Successful Facility Siting," 1996. Waste age, Internet Available: http://wasteage.com

[15] S. Sadek, E. F. Mutasem and F. Fadel, "Compliance Factors within A GIS-Based Framework for Landfill Siting," International Journal of Environmental Studies, Vol. 63, No. 1, 2006, pp. 71-86. doi:10.1080/00207230600562213

[16] A. Manu, Y. A. Twumasi, T. L. Coleman, I. A. Maiga, and K. Klaphake, "Database Development for Urban Planning Using Photogrametry and GIS Techniques: The Case of Niamey," Niger Paper presented at the 5th African Association of Remote Sensing of the Environment (AARSE Conference), Nairobi, 2004.

[17] T. L. Saaty, "Decision Making with Dependence and Feedback: The Analytical Network Process,” RWS Publication, Pittsburgh, 1996.
[18] T. L. Saaty, "Theory and Application of Analytical Network Process,” RWS Publication, Pittsbugh, 2005.

[19] E. W. L. Cheng and L. Heng, "Contractor Selection Using Analytical Network Process," Construction Engineering and Management, Vol. 131, No. 4, 2005, pp. 459-466. doi:10.1061/(ASCE)0733-9364(2005)131:4(459)

[20] T. P. IAEA, "Isotope-Based Investigations In the Chad Basin Aquifers. Abuja: Department of Hydrology and Hydrogeology,” Federal Ministry of Water Resources, 2005.

[21] C. Udomporn, W. Wanpen, C. Punya, M. William and L. Rungruang, "Landfill Site Characterization Kham Bon Village, Muang District, Khon Kaen Province, NE Thailand," International Journal of Environment and Waste Management, Vol. 4, No. 2-3, 2009, pp. 299-321.

[22] T. D. Kontos, D. P. Komilis and C. P. Halvadakis, "Siting MSW Landfills with a Spatial Multiple Criteria Analysis Methodology,” Waste Management, Vol. 25, No. 8, 2005, pp. 818-832. doi:10.1016/j.wasman.2005.04.002

[23] L. Zhilin, Z. Qing and G. Christopher, "Digital Terrain Modeling Principles and Methodology,” CRC Press, Florida, 2005.

[24] D. J. Lober, "Resolving the Siting Impasse: Modeling Social and Environmental Locational Criteria with Geographic Information System," American Planning Association, Vol. 61, No. 4, 1995, pp.482-495. doi:10.1080/01944369508975659

[25] G. Tchobanoglous, H. Theisen and S. A Vigil, "Integrated Solid Waste Management,” McGraw-Hill International Editions, 1993.

[26] E. V. Baxter, "Distributed Hydrologic Modeling Using GIS,” Vol. 48, $2^{\text {nd }}$ Ed., Kluwer Academic, Dordrecht, Boston, London, 2004.

[27] K. T. Chang, "Introduction to Geographic Information System”, $5^{\text {th }}$ Ed., Mc Graw-Hill International Edition, 2010. 